\title{
Factors affecting the in vitro production of bovine embryos in a commercial program
}

\author{
Fatores que afetam a produção in vitro de embriões bovinos em programa comercial \\ Factores que afectan la producción in vitro de embriones bovinos en un programa comercial
}

Received: 01/22/2021 | Reviewed: 01/25/2021 | Accept: 02/01/2021 | Published: 02/09/2021

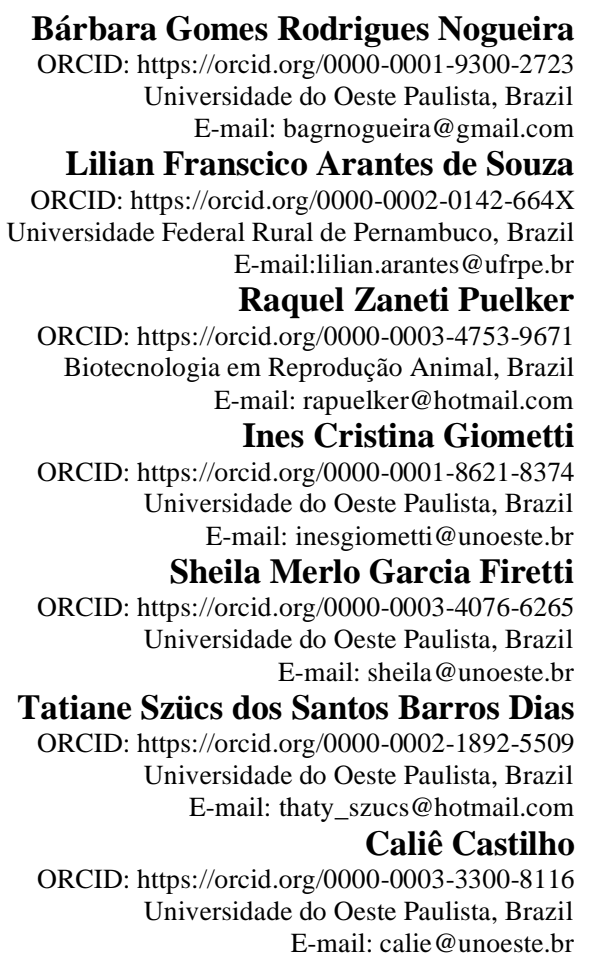

\begin{abstract}
Variability in the production of bovine blastocysts per session of ultrasound-guided follicularaspiration(OPU) is still an obstacle in commercial production. Thus, the objective of the current work was to verify factors that influence in vitro embryo production (PIVE), using data from a commercial laboratory.Data from 2014 to 2016 were analyzed, referring to 799 OPU sessions of adult bovine females of the breeds: Nelore $(n=83)$, Girolando $(n=73)$, Brangus $(n=49)$, HPB $(n=20)$, and Senepol $(n=10)$. The influence of five variables was analyzed: breed, genetic group, frequency of aspiration, type of semen (sexed/conventional), and seasonality (spring/summer vs. autumn/winter) on the rate of viable oocytes, cleavage, and blastocyst production (bl). The protocols for the in vitroproduction of embryos (IVP) followed the routine established by the partner laboratory of the present study. The statistical analysis of the data was performed using SAS, with the Chi-square test.The Girolando and Nelore breeds had a higher $(\mathrm{p}=0.0001)$ number of blastocysts/OPU session, as well as the Bos indicus blood group.Blastocyst production was higher ( $\mathrm{p}=0.0059)$ with sexed semen compared to conventional semen $(6.6 \times 5.2 \mathrm{bl} / \mathrm{OPU}$ session); a higher frequency of aspirations also increased $(\mathrm{p}=0.005)$ the number of bl/OPU session ( $7.7 \times 5.9)$. We conclude that the in vitro production of bovine embryos is influenced by the analyzed factors and knowledge of these variables could guide the commercial use of OPU-PIVE.
\end{abstract}

Keywords: Blastocyst; Bos indicus; Girolando; Ultrasound-guided follicular aspiration.

\section{Resumo}

A variabilidade na produção de blastocisto bovinos por sessão de aspiração folicular guiada por ultrassom (OPU) ainda é um entrave na produção comercial. Assim,objetivou-se verificar os fatores que influenciam a produção de embrião in vitro(PIVE), utilizando dados de um laboratório comercial. Foram analisados dados do ano de 2014 a 2016, referentes a 799 sessões de OPU de fêmeas bovinas adultas das raças: Nelore $(n=83)$, Girolando $(n=73)$, Brangus $(n=49)$, HPB $(n=20)$ e Senepol $(n=10)$. Analisou-se a influência de cinco variáveis: raça, grupamento genético, frequência de aspiração, tipo de sêmen (sexado/convencional) e sazonalidade (primavera/verão vs outono/inverno) sobre a taxa de oócitos viáveis, clivagem e produção de blastocisto (bl). Os protocolos para a produção de embriões in vitro (PIV)seguiram a rotina estabelecida pelo laboratório parceiro do presente estudo. A análise estatística dos dados foi realizada utilizado o SAS, empregando-se o Teste Qui-quadrado. As raças Girolando e Nelore apresentaram maior 
( $\mathrm{p}=0,0001)$ número de blastocisto/sessão de OPU, assim como o grupamento sanguíneo Bosindicus. A produção de blastocisto foimaior ( $\mathrm{p}=0,0059)$ com sêmen sexado em relação ao convencional ( 6,6 x 5,2 bl/sessão OPU); a frequência maior de aspirações também elevou $(\mathrm{p}=0,005)$ o número de bl/sessão OPU $(7,7$ x 5,9). Concluímos que a produção in vitro de embriões bovinos é influenciada pelos fatores analisados e conhecer estas variáveis pode nortear o emprego comercial da OPU-PIVE.

Palavras-chave: Blastocisto; Bos indicus; Girolando; Aspiração folicular guiada por ultrassom.

\section{Resumen}

La variabilidad en la producción de blastocistos bovinos por sesión de aspiración folicular guiada por ultrasonido (OPU) sigue siendo un obstáculo en la producción comercial. Así, el objetivo fue verificar los factores que influyen en la producción de embriones in vitro (PIVE), utilizando datos de un laboratorio comercial. Se analizaron datos del año 2014 al 2016, referidos a 799 sesiones de OPU de hembras bovinas adultas de las razas: Nellore $(\mathrm{n}=83)$, Girolando $(\mathrm{n}=73)$, Brangus $(n=49)$, HPB $(n=20)$ y Senepol $(n=10)$. Se analizó la influencia de cinco variables: raza, grupo genético, frecuencia de aspiración, tipo de semen (sexado / convencional) y estacionalidad (primavera / verano vs otoño / invierno) sobre la tasa de ovocitos viables, clivaje y producción de blastocistos (licenciado en Derecho). Los protocolos para la producción de embriones in vitro (PIV) siguieron la rutina establecida por el laboratorio socio del presente estudio. El análisis estadístico de los datos se realizó mediante el SAS, mediante la prueba de Chi-cuadrado. Las razas Girolando y Nelore tuvieron un mayor número $(\mathrm{p}=0,0001)$ de sesiones de blastocistos / OPU, así como el grupo sanguíneo Bos indicus. La producción de blastocistos fue mayor $(\mathrm{p}=0,0059)$ con semen sexado en comparación con el semen convencional $(6,6$ x 5,2 bl / sesión de OPU); la mayor frecuencia de aspiraciones también aumentó $(\mathrm{p}=0,005)$ el número de sesiones bl / OPU (7,7 x 5,9). Concluimos que la producción in vitro de embriones bovinos está influenciada por los factores analizados y conocer estas variables puede orientar el uso comercial de OPU-PIVE.

Palabras clave: Blastocisto; Bos indicus; Girolando; Aspiración folicular guiada por ecografia.

\section{Introduction}

Commercial work with OPU-PIVE started in Brazil with the implementation of the first laboratory in 1998. These techniques were leveraged by beef exports, which have gained impetus since 2002, demanding greater productive efficiency from producers in order to meet world demand for meat.Due to the fact that the Nelore herd adapted extraordinarily to OPUPIVE, its use quickly spread among ranchers, reaching more than $80 \%$ of the total embryos transferred (Viana, 2008). Since then, Brazil has been a leader in embryos produced in vitro (PIVE) (Perry, 2015).

When PIVE is used commercially, together with the follicular puncture technique guided by ultrasound (ovum pick up - OPU) to obtain oocytes, it is possible to maximize the productive potential of herds, increase the number of offspring, reduce the interval between generations, and accelerate animal genetic improvement (Varago et al., 2008), even allowing females with acquired reproductive pathologies to be used (Bueno and Beltran, 2008). Bovine IVP technology has contributed to accelerated genetic gain in dairy breeds, primarily because of sexed semen and genomics (Ferré et al., 2020a). Thus, these techniques present considerable advances and advantages compared to other breeding programs, enabling their large-scale application and the export of this model to several Latin American countries and other continents (Bols et al., 2012).

Despite the great potential and evolution of OPU-PIVE in recent years, these biotechniques present some limiting factors, with variability in results regarding blastocyst (10 to 40\%)(Lonergan and Fair, 2008; Rizos et al., 2008) and pregnancy rates (30 to 50\%)Trigal et al., 2012; Holguín et al., 2013) being one of the most relevant,and which directly influences commercial success.

Methods of in vitro culture have improved significantly in the last 15 years (Blondin, 2015; Ferré et al., 2020b), and the general conditions of embryonic production are well established, however there is still variability in the results, which could be credited to the origin of the oocytes.

In commercial works the use of female oocyte donors of different breeds and origins, with different management systems, as well as different protocols and technicians, highlights the need for research that portrays the reality of commercial production in Brazil, contributing to the improvement or regularity of the final indices. 
The objective of this analysis is to point out factors that affect the final results of blastocyst production in order to provide consistent data on the limitations found in the routine of a medium-sized commercial laboratory.

\section{Methodology}

\section{Location}

The current study was conducted using retrospective data provided by a commercial laboratory for in vitro embryo production, located in the municipality of PresidentePrudente, west of the State of São Paulo (Latitude $22^{\circ} 07^{\circ} \mathrm{S}$ and Longitude $\left.51^{\circ} 23^{\prime}\right)$.

Data from 2014 to 2016 were used, referring to 235 bovine females, adults, oocyte donors, of the breeds: Nelore, Girolando, Brangus, Holstein, and Senepol from different locations. The animals were reared under different management conditions according to the routine established in each property and were aspirated at least 2 and at most 17 times. The vast majority of consultations were restricted to a $200 \mathrm{~km}$ radius covering the western region of the state of São Paulo, eastern Mato Grosso do Sul, and northwestern Paraná.

\section{Cattle}

Data were analyzed from 235 female donors of the breeds Nelore ( $n=83)$, Girolando ( $n=73)$, Brangus ( $n=49)$, Holstein $(n=20)$, and Senepol $(n=10)$, submitted to a total of 799 sessions of follicular aspiration guided by ultrasound (OPU).

\section{Ovum pick-up (OPU)}

Follicular aspiration was performed by a single trained technician. Briefly, each visible follicle $>2$ mm in diameter was aspirated using a real-time B-mode ultrasound scanner (Mindray 2200; Mindray Bio-Medical Electronics, Shenzhen, China), a 7.5 MHz convex array transducer coupled to the intravaginal device (Watanabe Tecnologia Aplicada, São Paulo, Brazil), and a stainless steel guide. Follicular puncture was performed using a disposable $18 \mathrm{G}$ hypodermic needle (Becton Dickinson, Curitiba, PR, Brazil) connected to a $50 \mathrm{~mL}$ tube (Corning, Acton, MA, USA) via a silicon tube (0.8 m long; 2 mm id). Aspiration was performed using a vacuum pump (WTA model BV-003, Watanabe Tecnologia Aplicada, São Paulo, Brazil) with a negative pressure between 60 and $80 \mathrm{mmHg}$. The OPU medium was DPBS (Nutricell - Nutrientes Celulares, São Paulo, Brazil), 0.05\% sodium heparin (5000 IU/mL, Hemofol@, Cristália Produtos Químicos Farmacêuticos, São Paulo, Brazil), and 1\% fetal bovine serum (Gibco®, Thermo Fisher Scientific, Massachusetts, United States).

OPUs were performed on the property of origin of each animal, where cumulus-oocyte complexes (COC's) were classified according to the presence of cumulus cells and the aspect of the ooplasm (Seneda et al., 2001). After selection, only atretic oocytes were discarded and the remainder were deposited in cryotubes containing maturation medium. The transport/maturation medium was TCM 199 (Gibco Life Technologies, Grand Island, NY, USA) supplemented with 25 mM HEPES (Sigma H-0763), 10\% fetal calf serum (FCS), $50 \mu \mathrm{L} / \mathrm{mL}$ gentamycin sulfate (Schering-Plough, São Paulo, SP, Brazil), $0.5145 \mu \mathrm{g} / \mathrm{mL}$ follicle-stimulating hormone (FSH) (Folltropin ${ }^{\circledR}$, Bioniche Animal Health, Ontario, $146 \mathrm{Canada}$ ), $22 \mu \mathrm{g} / \mathrm{mL}$ pyruvate (Biochemical ${ }^{\circledR} 44094$, Sigma-Aldrich, Saint Louis, United States), $50 \mu \mathrm{g} / \mathrm{mL}$ luteinizing hormone (LH) (Lutropin ${ }^{\circ}$, Bioniche Animal Health, Ontario, Canada), and $1 \mu \mathrm{g} / \mathrm{mL}$ estradiol (Sigma® E-2758, Sigma-Aldrich, Saint Louis, United States).

The cryotubes were aerated using a standard gas mixture $(5 \% \mathrm{CO} 2,5 \% \mathrm{O} 2$, and $90 \% \mathrm{~N} 2)$ and sent to the laboratory in oocyte transport incubators $\left(\mathrm{WTA} \AA\right.$, Cravinhos, Brazil) at a controlled temperature $\left(37^{\circ} \mathrm{C}\right)$. 


\section{In vitro embryo production}

The in vitro procedures, IVM (in vitro maturation), IVF (in vitro fertilization), and IVC (in vitro cultivation), were performed according to Castilho et al. (2007) adapted by the analyzed laboratory.

Briefly, in the laboratory, the cryotubes were uncapped and placed in incubators with a 5\% $\mathrm{CO} 2$ atmosphere and a temperature of $38.5^{\circ} \mathrm{C}$ with maximum humidity. After 22 to 24 hours for IVM, in vitro fertilization (IVF) was performed with conventional or sexed semen after thawing in a water bath at $35^{\circ} \mathrm{C}$ for 30 seconds. The semen was washed by centrifugation through a $45 \%$ to $90 \%$ Percoll gradient at $200 \times$ g for 9 minutes in order to separate mobile spermatozoa. Fecundation was performed in drops with $70 \mu \mathrm{L}$ or $40 \mu \mathrm{L}$ of TALP medium containing 20 oocytes for, respectively conventional or sexed semen. The TALP medium was supplemented: $10 \mu \mathrm{g} / \mathrm{mL}$ heparin (Sigma ${ }^{\circledR}$ H-3149, Sigma-Aldrich, Saint Louis, United 158 States), $22 \mu \mathrm{g} / \mathrm{mL}$ pyruvate

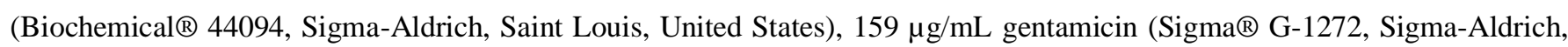
Saint Louis, United States), bovine serum albumin (BSA; Sigma ${ }^{\circledR}$ A-3311, Sigma-Aldrich, Saint Louis, United States), PHE solution, $2 \mu$ M penicillin (Sigma ${ }^{\circledR}$ P-4875, Sigma-Aldrich, Saint Louis, United States), $1 \mu$ M hypotaurine (Sigma ${ }^{\circledR} 162$ H-1384,

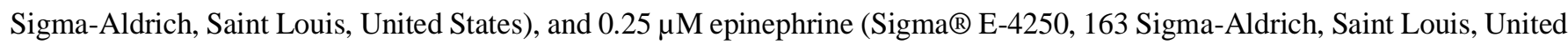
States). After centrifugation of the semen, the concentration of the sperm was adjusted to $1 \times 10^{6}$ spermatozoa/mL, sperm was capacitated using heparin $(30 \mu \mathrm{g} / \mathrm{mL})$ and each fertilization drop received $3-4 \mu \mathrm{L}$ or $10 \mu \mathrm{L}$, respectively conventional or sexed semen.

After 15 to 24 hours of fertilization, potential zygotes were cultured in vitro in synthetic oviduct fluid (SOF) medium, supplemented with 5\% FCS and $0.5 \%$ BSA in drops with $90 \mu \mathrm{L}$. The cleavage rate, that is, embryos with more than 2 cells, was evaluated 48 to 72 hours after fertilization and the embryonic development (blastocyst rate) on the seventh day. The blastocyst rate was based on the total number of matured oocytes. The culture medium was renewed on the cleavage day and on the 5th day (Day 0: IVF).

\section{Analyzed variables}

The influence of five variables was analyzed: breed and genetic group (Bostaurustaurus, Bostaurusindicus and cross) of the donor, frequency of aspiration of donor, type of semen (sexed vs. conventional), and seasonality (spring/summer vs. autumn/winter) on the rates of: viable oocytes, cleavage, blastocysts, and blastocyst production per OPU session.

The influence of the genetic group was analyzed by grouping donors according to breed: Bostaurus (Holstein and Senepol), Bosindicus (Nelore), Bostaurus x Bosindicus (Brangus and Girolando).

In order to verify the influence of the number of times the donor was aspirated, females aspirated only once were excluded, with the following ranges established: 2 to 8 sessions and 9 to 17 OPU sessions.

The seasonality effect was evaluated by dividing follicular aspiration procedures into two groups according to the dates on which they were performed; spring/summer group, females aspirated between September 22 and March 20 and autumn/winter group aspirated between March 21 and September 21.

\section{Statistical analysis}

The statistical analysis of the data was performed using the computer program Statistical Analysis System for Windows (SAS Inst., Inc., Cary, NC) using the chi-square test, with an adopted significance level of 5\%.

\section{Results}

There was an effect of the donor's breed on the variables: viable oocytes, cleavage, and blastocystproduction (Table 1). The percentage of viable oocytes was higher in the Nelore and Brangus breeds $(\mathrm{p}<0.0001)$. However, the Nelore and Girolando breeds presented the highest $(\mathrm{p}<0.0001)$ blastocyst production per OPU session. 
Table 1. Recovery rates, viable oocytes, cleavage, blastocysts, and number of blastocysts per OPU session, according to the breed of donors used in the commercial in vitro production of bovine embryos.

\begin{tabular}{|c|c|c|c|c|c|c|}
\hline & $\begin{array}{l}\text { Nelore } \\
(n=83)\end{array}$ & $\begin{array}{c}\text { Girolando } \\
(n=73)\end{array}$ & $\begin{array}{c}\text { Brangus } \\
(n=49)\end{array}$ & $\begin{array}{c}\text { Holstein } \\
(n=20)\end{array}$ & $\begin{array}{c}\text { Senepol } \\
(n=10)\end{array}$ & $\mathrm{p}$-value \\
\hline $\begin{array}{l}\text { Recovered } \\
\text { oocytes }\end{array}$ & $\begin{array}{c}34.28^{\mathrm{a}} \\
(7268 / 212)\end{array}$ & $\begin{array}{c}31.02^{\mathrm{a}} \\
(10764 / 347)\end{array}$ & $\begin{array}{c}36.76^{\mathrm{a}} \\
(5440 / 148)\end{array}$ & $\begin{array}{c}19.53^{\mathrm{b}} \\
(840 / 43)\end{array}$ & $\begin{array}{c}28.86^{\mathrm{ab}} \\
(1414 / 49)\end{array}$ & 0.0051 \\
\hline $\begin{array}{l}\% \text { Viable } \\
\text { Oocytes }\end{array}$ & $\begin{array}{c}74.34^{\mathrm{a}} \\
(5403 / 7268)\end{array}$ & $\begin{array}{c}66.07^{\mathrm{b}} \\
(7112 / 10764)\end{array}$ & $\begin{array}{c}75.44^{\mathrm{a}} \\
(4104 / 5440)\end{array}$ & $\begin{array}{c}67.38^{\mathrm{b}} \\
(566 / 840)\end{array}$ & $\begin{array}{c}60.75^{\mathrm{c}} \\
(859 / 1414)\end{array}$ & 0.0001 \\
\hline$\%$ Cleavage & $\begin{array}{c}77.61^{\mathrm{b}} \\
(4193 / 5403)\end{array}$ & $\begin{array}{c}87.54^{\mathrm{a}} \\
(6226 / 7112)\end{array}$ & $\begin{array}{c}57.38^{\mathrm{d}} \\
(2355 / 4104)\end{array}$ & $\begin{array}{c}66.61^{\mathrm{c}} \\
(377 / 566)\end{array}$ & $\begin{array}{c}56.23^{\mathrm{d}} \\
(483 / 859)\end{array}$ & 0.0001 \\
\hline$\%$ Blastocysts & $\begin{array}{c}30.74^{\mathrm{a}} \\
(1661 / 5403)\end{array}$ & $\begin{array}{c}32.83^{\mathrm{a}} \\
(2335 / 7112)\end{array}$ & $\begin{array}{c}17.23^{\mathrm{c}} \\
(707 / 4104)\end{array}$ & $\begin{array}{c}21.55^{\mathrm{b}} \\
(122 / 566)\end{array}$ & $\begin{array}{c}14.44^{\mathrm{c}} \\
(124 / 859)\end{array}$ & 0.0001 \\
\hline $\begin{array}{l}\text { Blastocysts } \\
\text { /OPU }\end{array}$ & $\begin{array}{c}7.83^{\mathrm{a}} \\
(1661 / 212)\end{array}$ & $\begin{array}{c}6.73^{a} \\
(2335 / 347)\end{array}$ & $\begin{array}{c}4.78^{\mathrm{b}} \\
(707 / 148)\end{array}$ & $\begin{array}{c}2.84^{\mathrm{c}} \\
(122 / 43)\end{array}$ & $\begin{array}{c}2.53^{\mathrm{c}} \\
(124 / 49)\end{array}$ & 0.0001 \\
\hline
\end{tabular}

Different letters on the same line differ by the $5 \%$ chi-square test.

Source: Authors.

The genetic group influenced the analyzed variables $(\mathrm{p}<0.0001)$ (Table 2). When comparing donors from different genetic groups, the superiority ofBos indicus was observed, represented by the Nelore breed, followed by females from industrial crossbreeding (Bos indicus x Bos taurus), and lastly the Bos taurus sub-species with the lowest values.

Table 2. Viable oocyte rates, cleavage, blastocyst production, and number of blastocysts per OPU session according to the donor genetic group used in the commercial in vitro production of bovine embryos.

\begin{tabular}{lcccc}
\hline & Bos indicus & $\begin{array}{c}\text { Bos taurus x Bos } \\
\text { indicus }\end{array}$ & BosTaurus & p-value \\
\hline \% Viable Oocytes & $74.34^{\mathrm{a}}$ & $69.22^{\mathrm{b}}$ & $63.22^{\mathrm{c}}$ & 0.0001 \\
& $(5403 / 7268)$ & $(11216 / 16204)$ & $(1425 / 2254)$ & \\
\% Cleavage & $77.61^{\mathrm{a}}$ & $76.51^{\mathrm{a}}$ & $60.35^{\mathrm{b}}$ & 0.0001 \\
& $(4193 / 5403)$ & $(8581 / 11216)$ & $(860 / 1425)$ & \\
\% Blastocysts & $30.74^{\mathrm{a}}$ & $27.12^{\mathrm{b}}$ & $17.26^{\mathrm{c}}$ & 0.0001 \\
Blastocysts/OPU & $(1661 / 5403)$ & $(3042 / 11216)$ & $(246 / 1425)$ & \\
& $7.83^{\mathrm{a}}$ & $6.15^{\mathrm{b}}$ & $2.67^{\mathrm{c}}$ & 0.0001 \\
\hline
\end{tabular}

Different letters on the line differ by the $5 \%$ chi-square test. Source: Authors.

The rates of cleavage and blastocysts were higher $(\mathrm{p}<0.0001)$ in donors aspirated more frequently $(9$ to 17 times $)$, without, however, affecting the rate of viable oocytes (Table 3). 
Table 3. Viable oocyte rates, cleavage, blastocyst production, and number of blastocysts per OPU session according to the frequency of ultrasound-guided follicular aspiration (OPU) of donors, regardless of breed, used in the commercial in vitro production of bovine embryos.

\begin{tabular}{lccl}
\hline & $\begin{array}{c}\mathbf{2} \text { to } 8 \text { OPU } \\
(\mathbf{n = 5 9 0})\end{array}$ & $\begin{array}{c}\mathbf{9} \text { to 17 OPU } \\
(\mathbf{n = 1 8 3})\end{array}$ & p-value \\
\hline \% Viable Oocytes & 70.08 & 70.36 & 0.6699 \\
& $(13180 / 18805)$ & $(4829 / 6863)$ & \\
\% Cleavage & $74.50^{\mathrm{b}}$ & $78.28^{\mathrm{a}}$ & 0.0001 \\
& $(9819 / 13180)$ & $(3780 / 4829)$ & \\
\% Blastocysts & $26.41^{\mathrm{b}}$ & $29.49^{\mathrm{a}}$ & 0.0001 \\
& $(3481 / 13180)$ & $(1424 / 4829)$ & \\
Blastocysts/OPU & $5.68^{\mathrm{b}}$ & $7.74^{\mathrm{a}}$ & 0.0005 \\
\hline
\end{tabular}

Different letters on the line differ by the $5 \%$ chi-square test.

Source: Authors.

Cleavage and blastocyst rates were higher $(\mathrm{p}<0.0001)$ using sexed semen compared to conventional semen (Table 4$)$.

Table 4. Rates of cleavage, blastocyst, and blastocyst production per session of OPU according to the type of semen (sexed vs. conventional) used in the commercial in vitro production of bovine embryos.

\begin{tabular}{lccl}
\hline & $\begin{array}{c}\text { Sexed semen } \\
(\mathbf{n = 5 5 5})\end{array}$ & $\begin{array}{c}\text { Conventional semen } \\
(\mathbf{n = 2 1 8})\end{array}$ & p-value \\
\hline \% Cleavage & $81.61^{\mathrm{a}}$ & $61.19^{\mathrm{b}}$ & 0.0001 \\
& $(10362 / 12697)$ & $(3272 / 5347)$ & \\
\% Blastocysts & $30.08^{\mathrm{a}}$ & $21.13^{\mathrm{b}}$ & 0.0001 \\
Blastocysts/OPU & $(3819 / 12697)$ & $(1130 / 5347)$ & \\
& $6.57^{\mathrm{a}}$ & $5.18^{\mathrm{b}}$ & 0.0059 \\
\hline
\end{tabular}

Different letters on the line differ by the $5 \%$ chi-square test.

Source: Authors.

There was an influence of the season, as donors aspirated in the spring/summer seasons exhibited a higher number of viable oocytes in relation to autumn/winter. However, seasonality did not influence the rate of cleavage (0.5066) or embryonic production $(\mathrm{p}=0.403)$ (Table 5).

Table 5. Viable oocyte rates, cleavage, blastocyst production, and number of blastocysts per OPU session according to the time of ultrasound-guided follicular aspiration (OPU) from donors used in commercial in vitro production of bovine embryos in Brazil.

\begin{tabular}{lccc}
\hline & $\begin{array}{c}\text { Spring/Summer } \\
(\mathbf{n}=661)\end{array}$ & $\begin{array}{c}\text { Autumn/Winter } \\
(\mathbf{n = 1 1 4})\end{array}$ & p-value \\
\hline \% Viable Oocytes & $70.56^{\mathrm{a}}$ & $67.28^{\mathrm{b}}$ & 0.0001 \\
\% Cleavage & $(15581 / 22081)$ & $(2463 / 3661)$ & 74.70 \\
& 75.70 & $(1840 / 2463)$ & 0.2885 \\
\% Blastocysts & $(11794 / 15581)$ & 27.97 & \\
Blastocysts/OPU & 27.34 & $(689 / 2463)$ & 0.5129 \\
& $(4260 / 15581)$ & 6.00 & 0.7217 \\
\hline
\end{tabular}

Different letters on the line differ by the $5 \%$ chi-square test.

Source: Authors. 


\section{Discussion}

In the present study, data from a commercial laboratory in Brazil were evaluated and through retrospective analysis it was possible to observe that breed and blood group have a strong influence on embryonic production. Regardless of breed or blood group, the higher frequency of aspirations increased the cleavage and blastocyst rates, as well as which, the use of sexed semen showed higher rates of both cleavage and blastocysts. However, the spring/summer season, although improving oocyte quality, did not influence blastocyst production.

Oocyte recovery was not influenced by the breeds worked with at the analyzed laboratory, and in HPB donors the recovery was greater than the results presented in the literature. Follicular development in Nelore females (Figueiredo et al., 1997) is similar to that observed in HPB (Bo et al., 2003), Girolando (Castilho et al., 2000), Angus, Brahman, and Senepol females (Alvarez et al., 2000), however, differences are observed mainly in follicular diameters, number of waves per cycle, as well as in the number of follicles recruited per wave. Alvarez et al. (2000) observed a greater amount of small follicles (3 to 5 $\mathrm{mm}$ ) in the emergence of waves in Brahman (39 \pm 4 ) compared to Senepol (33 \pm 4$)$ or Angus females (21 \pm 4$)$. Nelore females submitted to the same climatic and nutritional conditions as HPB cows exhibit a greater number of recruited follicles (42.7 vs 19.7) per follicular wave (Bastos et al., 2010).

This difference in the number of follicles recruited directly influences the application of OPU in terms of oocyte recovery and, consequently, embryonic production (Ferré et al., 2020b). In females of the Nelore breed, recovery is greater per session of OPU, around 30 to 38 total oocytes, when compared to means of from 6.5 to 16 COCs in the Holstein breed (Pontes et al., 2010; Ratto et al., 2011; Gimenes et al., 2015). Animals of the Girolando breed, due to crossbreeding and their different degrees of blood from the HPB breed (Bostaurus) with the Gir breed (Bosindicus), showed varying oocyte recovery according to the blood grade, from 20.4 to 31.4 oocytes per OPU session (Pontes et al, 2011).

The rate of viable oocytes, that is, the quality of the oocytes was influenced by breed and seasonality, however, this was not always a safe predictor for embryonic production. In donors of the Brangus and Holstein breeds the high rates of viable oocytes did not influence the production of blastocysts. However, the Senepol breed presented the lowest rate of viable oocytes, also resulting in low blastocyst production. On the other hand, seasonality strongly influenced the rate of viable oocytes but did not affect the rates of cleavage and blastocysts.

The oocytes that are selected for IVP are evaluated by morphological characteristics depending on the number of cumulus cells and homogeneity of the ooplasm (Seneda et al., 2001).This classification is related to oocyte competence for development up to the blastocyst stage, and according to Merton et al. (2003), oocyte quality is often defined as the ability to produce a blastocyst within an IVP system. In general, better quality oocytes generate higher rates of blastocysts (Merton et al., 2003), however, class 3 oocytes (mild signs of atresia) showed better rates when compared to classes 1 and 2 (Blondin and Sirard, 1995). Therefore, in order to obtain the largest number of embryos in commercial programs, normally only oocytes with a high level of degeneration are excluded from production (Pontes et al., 2011).

Although culture conditions can impact the embryo's early development potential, the intrinsic quality of the oocyte is the key factor that determines oocyte competence up to the blastocyst stage (Blondin \& Sirard, 1995). Genetic improvement for milk production, along with changes in nutrition and management, has been associated with declining fertility in dairy cows (Snjiders et al., 2000). In studies conducted by the group of Prof. Baruselli, it was possible to observe that $B$. taurus females produce less blastocysts by OPU-PIVE when compared to B. indicus donors(Sales et al., 2015; Gimenes et al., 2015). However, in another study evaluating commercial data, embryo production (5.5 blastocysts) was higher in the Girolando breed, compared to the Gir (Bosindicus) and HPB breeds (Bostaurus, Pontes et al., 2011). However, oocyte competence does not depend only on intrinsic factors, but is also related to the type of protocol used in the laboratory, the semen, and method of obtaining oocytes 
(Merton et al., 2003). Several authors have emphasized the improvement of oocyte quality in the supplementation of oocytes with antioxidant substances, to reduce oxidative stress (Oliveira et al., 2020).

In the current study, both the in vitro protocol and media, as well as the technique used, were the same and it is known that the type of media used in the cultivation of oocytes and embryos has an important influence on embryonic development (van Wagtendonk-de Leeuw et al., 1998). Part of these variations may be due to the different capacities of bulls to produce embryos and a high male effect on the efficiency of a commercial IVP program (Palma \& Sinowatz, 2004). In addition to the type of semen (conventional vs. sexed), which can markedly affect the efficiency of an in vitro fertilization program (Palma et al., 2008, Ferré et al., 2020b).

The type of semen used influenced the rate of cleavage and embryonic development in vitro and, to our surprise, sexed semen showed better rates when compared to conventional semen. Some researchers have reported that using sexed semen has no effects on blastocyst development rates (Carvalho et al., 2010; Lu and Seidel, 2004), while others report greater cleavage, but lower blastocyst rates(Blondin et al., 2009). Current in vitro procedures attempt to compensate for decreased embryonic development with the use of sexed semen (Rath et al., 2013), by increasing the concentration of sperm in the fertilization drop (Barceló-Fimbres et al., 2011). Increasing the concentration in the fertilization drop was one of the strategies used in the evaluated laboratory, in which sexed semen was most used for the Girolando breed. This is probably the reason for the better rates of embryonic development displayed in the current work.However, it is not only the low concentration of sperm per straw that is responsible for the low and variable results obtained with sexed semen. Morphological alterations in sexed spermatozoids resulting from the flow cytometry process may also be responsible for the impairment in embryonic development rates (Palma et al., 2008). Therefore, detecting bulls that show the best results in IVP with sexed semen is another strategy adopted by commercial laboratories to minimize the low production of blastocysts. Conventional or sexed semen from 3 different bulls were tested and in general the conventional semen produced more blastocysts, but this difference was inherent to the bull (Nascimento et al., 2015).

In the present study, there was variation in the intervals between OPU sessions, as it is not possible to maintain a specific routine in a commercial laboratory, which works according to demand. However, in the majority of cases, the same cows were aspirated at intervals of approximately 30 days. There was an increase in cleavage and blastocysts when statistically analyzing donors aspirated 9 to 17 times compared to those aspirated 2 to 8 times during the evaluated period. There is no physiological explanation for this increase, but we believe that this greater efficiency is related to the fact that the females that present the best results in PIVE are the ones that owners use most often in OPU and, consequently, they present the best results.

These biotechniques are extremely versatile and when well conducted result in extraordinary genetic gains for the meat or milk producer, however, the results still present variability, including the factors presented in the current work.

\section{Conclusion}

We conclude that the in vitro production of blastocysts in commercial programs is highly influenced by the breed and blood group of the donor, as well as the sexing of the semen and frequency of aspirations.

Knowledge of these factors can guide the use of OPU-PIVE in order to minimize variability in the results obtained commercially using these biotechniques.

\section{Referências}

Alvarez, P., Spicer, L. J., Chase, C. C., Payton, M. E., Hamilton, T. D., Stewart, R. E., \& Wettemann, R. P. (2000). Ovarian and endocrine characteristics during an estrous cycle in Angus, Brahman, and Senepol cows in a subtropical environment. Journal of Animal Science, 78(5), 1291-1302.

Barceló-Fimbres, M., Campos-Chillón, L., \& Seidel Jr, G. (2011). In vitro fertilization using non-sexed and sexed bovine sperm: Sperm concentration, sorter 
pressure, and bull effects. Reproduction in Domestic Animals, 46(3), 495-502.

Bastos, M. R., Mattos, M. C. C., Meschiatti, M. A. P., Surjus, R. S., Guardieiro, M. M., Mourão, G. B., . . Sartori, R. (2010). Ovarian function and circulating hormones in nonlactatingNelore versus Holstein cows. Acta_Scientiae_Veterinariae. (Abstract in press)

Blondin, P., \& Sirard, M.-A. (1995). Oocyte and follicular morphology as determining characteristics for developmental competence in bovine oocytes. Molecular Reproduction and Development, 41(1), 54-62.

Blondin, P., Beaulieu, M., Fournier, V., Morin, N., Crawford, L., Madan, P., \& King, W. A. (2009). Analysis of bovine sexed sperm for IVF from sorting to the embryo. Theriogenology, 71(1), 30-38.

Blondin, P. (2015). Status of embryo production in the world. Animal Reproduction, 12(3), 356-358.

Bó, G. A., Baruselli, P. S., \& Martínez, M. F. (2003). Pattern and manipulation of follicular development in Bos indicus cattle. Animal Reproduction Science, $78(3-4), 307-326$.

Bols, P. E. J., Jorssen, E. P. A., Goovaerts, I. G. F., Langbeen, A., \& Leroy, J. L. M. R. (2012). High throughput non-invasive oocyte quality assessment: the search continues. Anim Reprod, 9(3), 420-425.

Bueno, A. P., \& Beltran, M. P. (2008). Produção in vitro de embriões bovinos. Recuperado de http://www.faef.revista.inf.br/imagens_arquivos/arquivos_destaque/pyqdj1dprseHFgW_2013-6-13-15-24-57.pdf

Carvalho, J. O., Sartori, R., Machado, G. M., Mourão, G. B., \& Dode, M. A. N. (2010). 365 Quality assessment of bovine cryopreserved sperm after sexing by flow cytometry and its use for in vitro embryo production. Reproduction, Fertility and Development, $22(1), 339$.

Castilho, C., Gambini, A. L. G., Fernandes, P., Trinca, L. A., Teixeira, A. B., \& Barros, C. M. (2000). Synchronization of ovulation in crossbred dairy heifers using gonadotrophin-releasing hormone agonist, prostaglandin F2a and human chorionic gonadotrophin or estradiol benzoate. Brazilian Journal of Medical and Biological Research, 33(1), 91-101.

Castilho, C., Assis, G. S., \& Garcia, J. M. (2007). Influência do diâmetro e da fase folicular sobre a competência in vitro de oócitos obtidos de novilhas da raça Nelore. Arquivo Brasileiro de Medicina Veterinária e Zootecnia, 59(2), 288-294.

Ferré, L. B., Kjelland, M. E., Strøbech, L. B., Hyttel, P., Mermillod, P., \& Ross, P. J. (2020). Review : Recent advances in bovine in vitro embryo production : reproductive biotechnology history and methods. Animal, The International Journal of Animal Biosciences, 14(5), 991-1004.

Ferré, L. B., Kjelland, M. E., Taiyeb, A. M., \& Ross, F. C. P. J. (2020). Recent progress in bovine in vitro-derived embryo cryotolerance : Impact of in vitro culture systems , advances in cryopreservation and future considerations. Reproduction in Domestic Animals, 55, 659-676.

Figueiredo, R. A., Barros, C. M., Pinheiro, O. L., \& Soler, J. M. P. (1997). Ovarian follicular dynamics in nelore breed (Bos indicus) cattle. Theriogenology, $47(8), 1489-1505$.

Gimenes, L. U., Ferraz, M. L., Fantinato-Neto, P., Chiaratti, M. R., Mesquita, L. G., Sá Filho, M. F., \& Baruselli, P. S. (2015). The interval between the emergence of pharmacologically synchronized ovarian follicular waves and ovum pickup does not significantly affect invitro embryo production in Bos indicus, Bos taurus, and Bubalus bubalis. Theriogenology, 83(3), 385-393.

Holguín, G., Montaña, D., \& Valbuena, D. (2013). Corpus luteum diameter and embryo developmental stage are associated with pregnancy rate : data analysis from 17,521 embryo transfers from a commercial in vitro bovine embryo production program. Animal Reproduction, 10(2), 106-111.

Lonergan, P., \& Fair, T. (2008). In vitro-produced bovine embryos-Dealing with the warts.Theriogenology,69(1),17-22.

Lu, K. ., \& Seidel, G. (2004). Effects of heparin and sperm concentration on cleavage and blastocyst development rates of bov ine oocytes inseminated with flow cytometrically-sorted sperm. Theriogenology, 62(5), 819-830.

Merton, J. S., De Roos, A. P. W., Mullaart, E., De Ruigh, L., Kaal, L., Vos, P. L. A. M., \& Dieleman, S. J. (2003). Factors affecting oocyte quality and quantity in commercial application of embryo technologies in the cattle breeding industry. Theriogenology, 59(2), 651-674.

Nascimento, P. S., Chaves, M. S., Dos Santos Filho, A. S., Guido, S. I., Guerra, M. M. P., \& Bartolomeu, C. C. (2015). Produção in vitro de embriões utilizandose sêmen sexado de touros 5/8 girolando. Ciencia Animal Brasileira, 16(3), 358-368.

Oliveira, L. R. M., Santos, M. V. O., Bertini, L. M., Pereira, A. F. (2020). Bioguided isolation of compounds with antioxidant activity to improve the in vitro maturation of mammalian oocytes. Research, Society and Development, 9(8), 1-20.

Palma, G. A., \& Sinowatz, F. (2004). Male and Female Effects on the In Vitro Production of Bovine Embryos. Anatomia, Histologia, Embryologia: Journal of Veterinary Medicine Series C, 33(5), 257-262.

Palma, G. A., Olivier, N. S., Neumüller, C., \& Sinowatz, F. (2008). Effects of sex-sorted spermatozoa on the efficiency of in vitro fertilization and ultrastructure of in vitro produced bovine blastocysts. Journal of Veterinary Medicine Series C: Anatomia Histologia Embryologia, 37(1), 67-73.

Perry, G. (2015). IETS Report 2014. 1-10.

Pontes, J. H. F., Silva, K. C. F., Basso, A. C., Rigo, A. G., Ferreira, C. R., Santos, G. M. G., \& Seneda, M. M. (2010). Large-scale in vitro embryo production and pregnancy rates from Bos taurus, Bos indicus, and indicus-taurus dairy cows using sexed sperm. Theriogenology, 74(8), 1349-1355.

Pontes, J. H. F., Melo Sterza, F. A., Basso, A. C., Ferreira, C. R., Sanches, B. V., Rubin, K. C. P., \& Seneda, M. M. (2011). Ovum pick up, in vitro embryo production, and pregnancy rates from a large-scale commercial program using Nelore cattle (Bos indicus) donors. Theriogenology, 75(9), 1640-1646.

Rath, D., Barcikowski, S., de Graaf, S., Garrels, W., Grossfeld, R., Klein, S., \& Washausen, S. (2015). Sex selection of sperm in farm animals: status report and 
Research, Society and Development, v. 10, n. 2, e16110212264, 2021

(CC BY 4.0) | ISSN 2525-3409 | DOI: http://dx.doi.org/10.33448/rsd-v10i2.12264

developmental prospects. Reproduction,149(3), X1.

Ratto, M. H., Peralta, O. A., Mogollon, G., Strobel, P., \& Correa, J. (2011). Transvaginal ultrasound-guided cumulus oocyte complexes aspiration and in vitro embryo production in suckled beef and lactating dairy cattle on pasture-based management conditions. Animal Reproduction Science, 129(1-2), 1-6.

Rizos, D., Bermejo-Alvarez, P., Gutierrez-Adan, A., \& Lonergan, P. (2008). Effect of duration of oocyte maturation on the kinetics of cleavage, embryo yield and sex ratio in cattle. Reproduction, Fertility and Development, 20(6), 734.

Sales, J. N. S., Iguma, L. T., Batista, R. I. T. P., Quintão, C. C. R., Gama, M. A. S., Freitas, C., \& Baruselli, P. S. (2015). Effects of a high-energy diet on oocyte quality and in vitro embryo production in Bos indicus and Bos taurus cows. Journal of Dairy Science, 98(5), 3086-3099.

Seneda, M. M., Esper, C. R., Garcia, J. M., Oliveira, J. A. de, \& Vantini, R. (2001). Relationship between follicle size and ultrasound-guided transvaginal oocyte recovery. Animal Reproduction Science, 67(1-2), 37-43.

Snijders, S. E. M., Dillon, P., O’Callaghan, D., \& Boland, M. P. (2000). Effect of genetic merit, milk yield, body condition and lactation number on in vitro oocyte development in dairy cows. Theriogenology, 53(4), 981-989.

Trigal, B., Gómez, E., Caamaño, J. N., Muñoz, M., Moreno, J., Carrocera, S., Martín, D., \& Diez, C. (2012). In vitro and in vivo quality of bovine embryos in vitro produced with sex-sorted sperm. Theriogenology, 78(7), 1465-1475.

Van Wagtendonk-de Leeuw, A., Aerts, B. J., \& den Daas, J. H. (1998). Abnormal offspring following in vitro production of bovine preimplantation embryos: A field study. Theriogenology, 49(5), 883-894.

Varago, F. C., Mendoça, L., \& Lagares, M. A. (2008). Produção in vitro de embriões bovinos: estado da arte e perspectiva de u ma técnica em constante evolução. Revista Brasileira de Reprodução Animal, 32, 100-109.

Viana, J. H. M. (2008). Produção de embriões bovinos in vivo (transferência de embriões - TE) e in vitro (Fecundação in vitro FIV) no Brasil: histórico, cenário atual e perspectivas. Anais doSimpósio de Reprodução de Bovinos, Pelotas, RS, Brasil,1. https://ainfo.cnptia.embrapa.br/digital/bitstream/CPACT-200909/11597/1/1_simposio_reproducao_bovinos.pdf 